\title{
TREATMENT OF OSTEO-ARTHRITIS OF THE HIP WITH INDOMETHACIN \\ A CONTROLLED CLINICAL TRIAL
}

BY

\author{
J. WANKA AND A. ST. J. DIXON \\ From the Chelsea and Kensington Rheumatism Units, \\ St. Mary Abbots Hospital and St. Stephen's Hospital, London
}

This paper reports a clinical trial of the effect of indomethacin compared with a placebo in the treatment of painful osteo-arthritis of the hip.

Indomethacin (1-(p-chlorobenzoyl)-5-methoxy2-methylindole-3-acetic acid) was given as a powder in gelatin capsules. The compressed tablet formulation which was used in previous trials both by ourselves (Wanka, Jones, Wood, and Dixon, 1964) and by others (Hart and Boardman, 1963), which has been found to undergo progressive hardening on storage affecting dispersion and absorption, was not used in this trial.
Osteo-arthritis of the hip has, in practice, a spectrum of clinical and radiological features and in order that the clinical material on which this trial was based should be reproducible, brief data on the patients who took part in this trial are given in Table $\mathbf{I}$ and representative $x$ rays in Fig. 1 (opposite).

Grading of $x$-ray appearances is based on a standard atlas (Council for International Organizations of Medical Sciences, 1963).

The trial, which was of a double-blind, singlecrossover clinical design, lasted 8 weeks. The

TABLE I

CLINICAL PARTICULARS OF 18 PATIENTS

\begin{tabular}{|c|c|c|c|c|c|c|c|c|c|c|}
\hline \multirow{2}{*}{$\begin{array}{r}\text { Patient } \\
\text { Number }\end{array}$} & \multirow{2}{*}{$\begin{array}{c}\text { Age } \\
\text { (yrs) }\end{array}$} & \multirow[b]{2}{*}{ Sex } & \multirow[b]{2}{*}{ Other Illnesses } & \multicolumn{2}{|c|}{ Severity (Grade 0-3) } & \multirow{2}{*}{$\begin{array}{c}\text { Duration of } \\
\text { Symptoms (yrs) }\end{array}$} & \multirow{2}{*}{ Hip } & \multicolumn{3}{|c|}{$X$-Ray Appearance of Osteo-arthritis } \\
\hline & & & & Effort Pain & Rest Pain & & & Type & Severity* & $\begin{array}{l}\text { Minimum Thickness } \\
\text { of Joint "Space" (mm.) }\end{array}$ \\
\hline 1 & 67 & $\mathbf{F}$ & None & 2 & 1 & 9 & $\mathbf{R}$ & $\underset{\mathbf{S}}{\mathbf{S}}$ & 4 & $<1$ \\
\hline 2 & 57 & $\mathbf{M}$ & None & 2 & 1 & 5 & $\mathbf{R}$ & $\mathbf{S}$ & 4 & $<1$ \\
\hline 3 & 78 & $\mathbf{M}$ & None & 1 & $\mathbf{0}$ & 4 & $\mathbf{R}$ & $\stackrel{S}{S}$ & $\begin{array}{l}3 \\
1\end{array}$ & $\begin{array}{l}2 \\
3\end{array}$ \\
\hline 4 & 58 & $\mathbf{M}$ & Obesity & 2 & 2 & 4 & $\mathbf{R}$ & $\mathbf{S}$ & $\begin{array}{l}4 \\
4\end{array}$ & $\begin{array}{l}<1 \\
<1\end{array}$ \\
\hline 5 & 60 & $\mathbf{M}$ & None & 2 & 0 & 10 & $\mathbf{R}$ & $\begin{array}{l}\mathbf{S} \\
\mathbf{S}\end{array}$ & $\begin{array}{l}3 \\
2\end{array}$ & $\begin{array}{l}<1 \\
<1\end{array}$ \\
\hline 6 & 53 & $\mathbf{M}$ & Arthrosis of elbows & 3 & 1 & 4 & $\mathbf{L}$ & $\mathbf{S}$ & $\begin{array}{l}1 \\
4\end{array}$ & $\begin{array}{r}2 \\
<1\end{array}$ \\
\hline 7 & 59 & $\mathbf{M}$ & None & 3 & 1 & 5 & $\mathbf{L}$ & $\stackrel{S}{S}$ & $\begin{array}{l}4 \\
4\end{array}$ & $\begin{array}{r}<1 \\
1\end{array}$ \\
\hline 8 & 74 & $\mathbf{M}$ & Depression & 3 & 2 & 11 & $\begin{array}{l}\mathbf{L} \\
\mathbf{R}\end{array}$ & $\begin{array}{l}\mathbf{S} \\
\mathbf{C}\end{array}$ & $\begin{array}{l}4 \\
3\end{array}$ & $\begin{array}{l}<1 \\
<1\end{array}$ \\
\hline 9 & 74 & $\mathbf{M}$ & Prostatectomy & 3 & 3 & 3 & $\mathbf{R}$ & $\begin{array}{l}\mathbf{C} \\
\mathbf{S}\end{array}$ & $\begin{array}{l}3 \\
4\end{array}$ & $\begin{array}{l}<1 \\
<1\end{array}$ \\
\hline 10 & 78 & $\mathbf{F}$ & $\begin{array}{c}4 \text { wks before study } \\
\text { Girdlestone }\end{array}$ & 3 & 1 & 14 & $\begin{array}{l}\mathrm{L} \\
\mathrm{R} * *\end{array}$ & $\mathbf{S}$ & 3 & $<1$ \\
\hline 11 & 72 & F & $\begin{array}{c}\text { operation right hip } \\
\text { Pernicious }\end{array}$ & 2 & 1 & 9 & R & $\stackrel{S}{C}$ & 4 & $\begin{array}{r}<1 \\
3 \\
<1\end{array}$ \\
\hline 12 & 62 & $\mathbf{F}$ & $\begin{array}{c}\text { anaemia } \\
\text { Hypertension; } \\
\text { obesity }\end{array}$ & 2 & 2 & 3 & $\begin{array}{l}\mathrm{L} \\
\mathrm{R}^{* *} \\
\mathrm{~L}\end{array}$ & $\begin{array}{l}\mathbf{S} \\
\mathbf{C}\end{array}$ & $\begin{array}{l}4 \\
3 \\
4\end{array}$ & $\begin{array}{r}<1 \\
2 \\
<1\end{array}$ \\
\hline 13 & 83 & $\mathbf{F}$ & None & 2 & 2 & 1 & $\mathrm{R}^{* *}$ & C & 1 & 4 \\
\hline 14 & 50 & $\mathbf{F}$ & Hypertension & 2 & 1 & 5 & & $\mathbf{S}$ & 2 & 2 \\
\hline 15 & 64 & $\mathbf{F}$ & None & 2 & 2 & 4 & $\mathbf{R}^{* *}$ & $\mathbf{S}$ & 1 & $\begin{array}{l}4 \\
3\end{array}$ \\
\hline 16 & 53 & $\mathbf{F}$ & Obesity; papilloma & 3 & 2 & 6 & $\mathbf{R}^{* *}$ & $\stackrel{S}{S}$ & 1 & 2 \\
\hline 17 & 61 & $\mathbf{F}$ & $\begin{array}{l}\text { of bladder } \\
\text { None }\end{array}$ & 2 & 1 & 1 & $\mathbf{R}$ & $\mathbf{S}$ & $\begin{array}{l}4 \\
2\end{array}$ & $\begin{array}{r}<1 \\
1\end{array}$ \\
\hline 18 & 73 & $\mathbf{F}$ & None & 2 & 1 & 4 & $\mathbf{L}^{* *}$ & $\begin{array}{l}\mathbf{C} \\
\mathbf{S}\end{array}$ & $\begin{array}{l}1 \\
3 \\
1\end{array}$ & $\begin{array}{r}3 \\
2\end{array}$ \\
\hline
\end{tabular}

* For grading see text. S (superior) or $\mathrm{C}$ (central) indicate main site of cartilage destruction. 


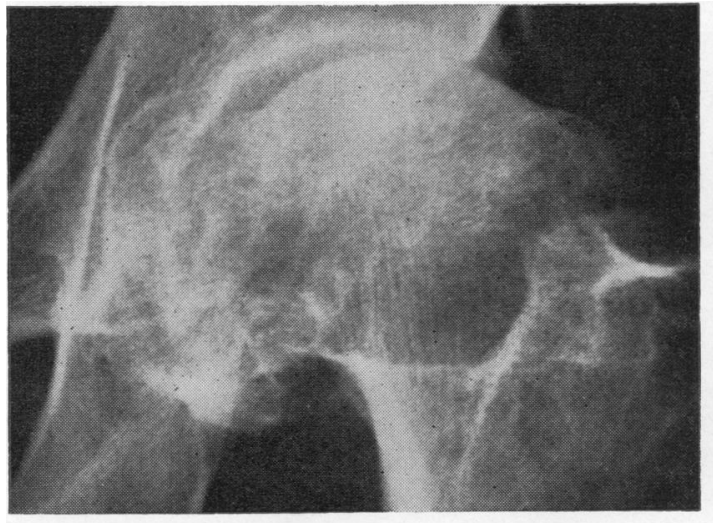

Case 6

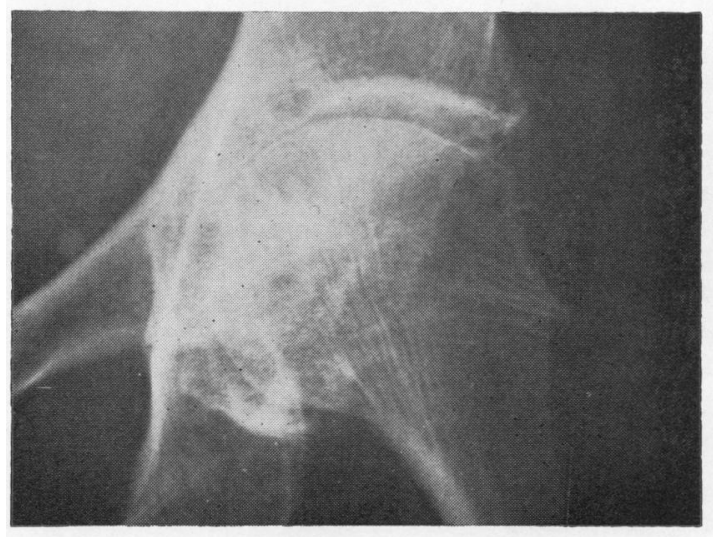

Case 13

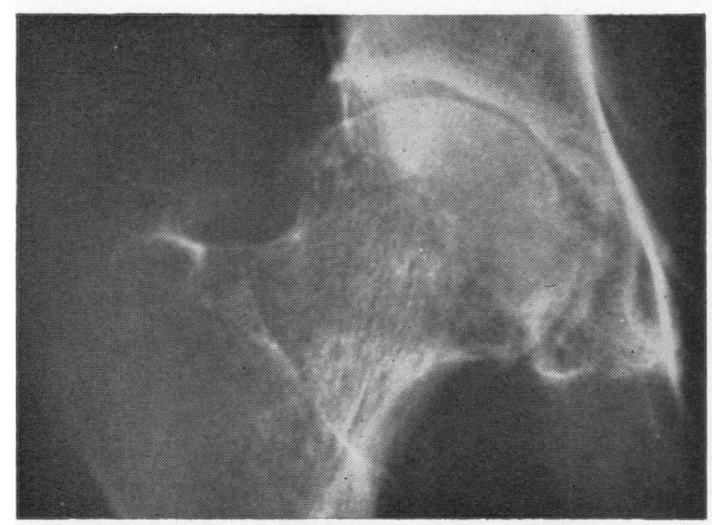

Case 17

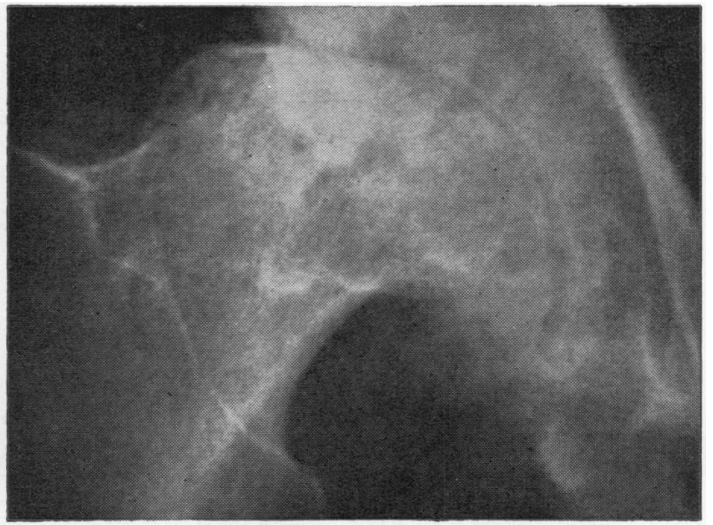

Case 7

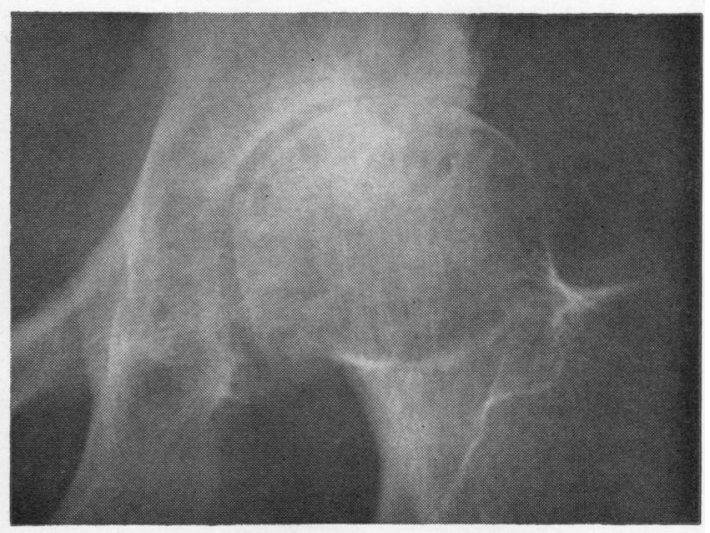

Case 15

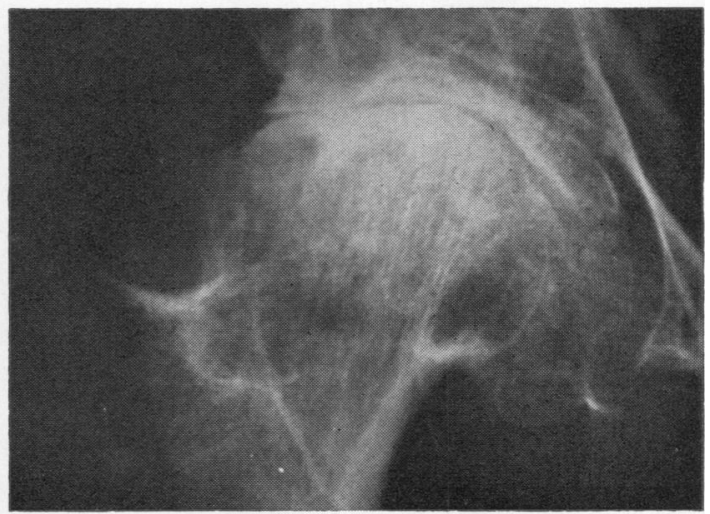

Case 18

Fig. 1.- $X$-ray appearance of hip joint in Cases $15,17,18,13,6$, and 7 . 
initial treatment was randomly allocated, the doses of indomethacin being as follows:

\begin{tabular}{c|c|c|c}
\hline Week & Dose (mg.) & $\begin{array}{c}\text { No. of } \\
\text { Daily Doses }\end{array}$ & Total Dose per Day \\
\hline 1 & 25 & 3 & 75 \\
2 & 50 & 2 & 100 \\
3 & 50 & 3 & 150 \\
4 & 50 & 3 & 150 \\
\hline
\end{tabular}

An identical number and sequence of capsules containing lactose were given for the alternative 4-week period. The patients were issued with numbered pre-packed bottles containing the appropriate daily dosage with instructions as to the number of tablets to be taken daily after food, and were told to return the bottles at their next visit with any of the capsules they had not taken In no case were more than two tablets returned at the end of each fortnight. The patients were assessed by the same observer at Weeks $0,2,4,6$, and 8 . None of the patients gave a history of peptic ulceration, and barium meal examinations, which were done on all of them before the start of the trial, were reported as normal, except for one patient who had a duodenal diverticulum.

Altogether twenty patients were selected for the trial and the findings for all but two are included in the assessment of results. One patient was withdrawn in Week 3 because he developed a urinary infection with some retention due to prostatic hypertrophy and had to undergo prostatectomy. A second patient stopped because of headache at the

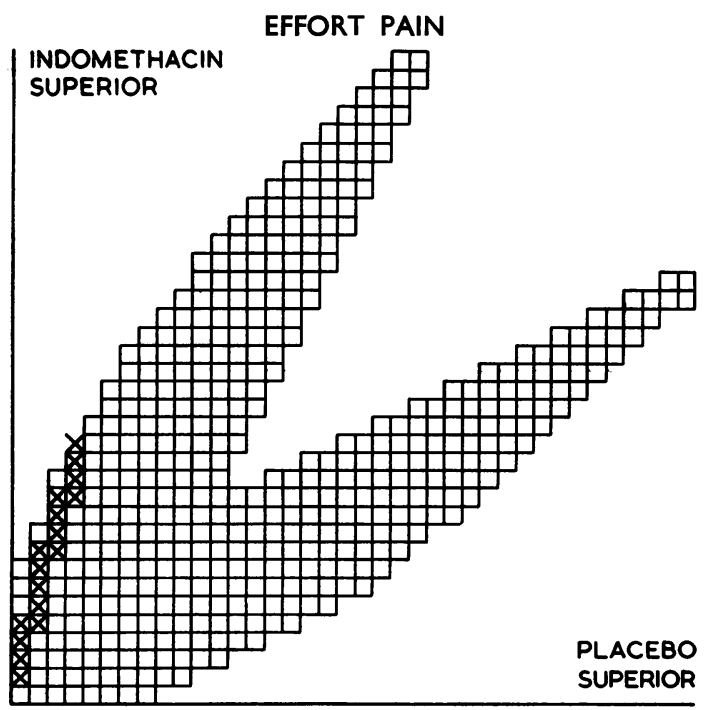

end of Week 5 of the trial when she was taking 75 mg. indomethacin per day; her results have not been included.

A third patient developed giddiness and indigestion during Week 7 of the trial while on indomethacin; she stopped her medication, but her results up to the beginning of Week 8 have been included.

The patients comprised eight men and ten women, whose ages ranged from 50 to 83 years (mean 65). Seven of them had predominantly unilateral and eleven bilateral hip pain. The therapeutic value was assessed in each patient at fortnightly intervals by the following criteria:

1. Patient preference, judged by pain on walking.

2. Patient preference, judged by pain at rest at night.

3. Ranges of hip movement in flexion, abduction, and rotation.

4. Adverse effects.

5. Laboratory findings.

\section{Results}

Patient Preference

The patients were asked to state if they had experienced more pain, the same amount of pain, or less pain, first on walking (Effort Pain) and second in bed (Rest Pain) as compared with the preceding 2-week period, The replies are charted in Fig. 2 (opposite) for both effort and rest pain. The "Net Preference" was estimated from the overall results of these two charts. Each patient's "Net Preference" was added to the sequential analysis chart (method of Bross, 1952) for effort and rest pain (Figs 3 and 4).

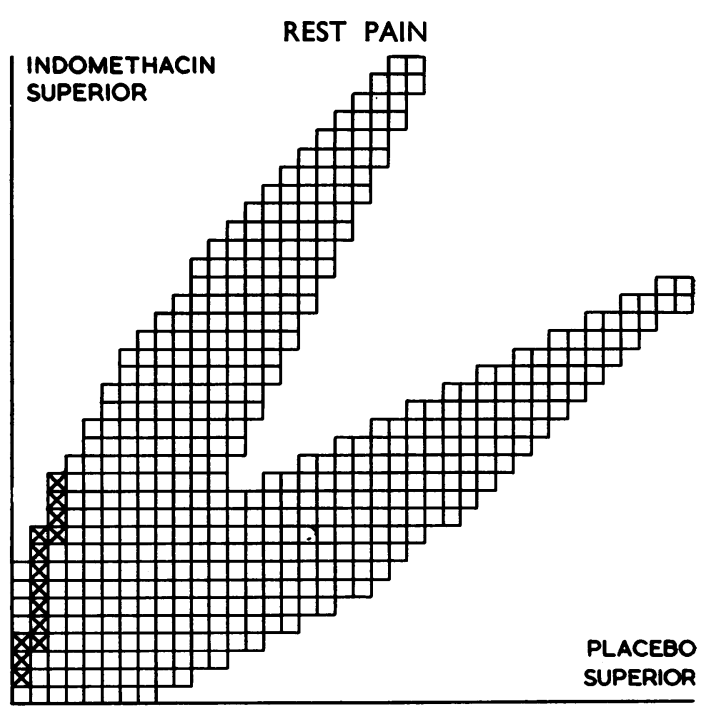

Figs 3 and 4.- Net Preference for the whole 8-week period of the trial for each type of treatment. Each patient is represented by a square on the chart. If the overall result is better for indomethacin, the square is added in the direction of the $\mathrm{X}$ axis; if the overall preference is for the placebo, the square is added in the direction of the $\mathrm{Y}$ axis. 


\section{PATIENT EFFORT PAIN} No.

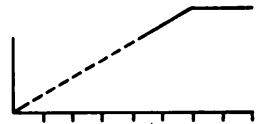

3

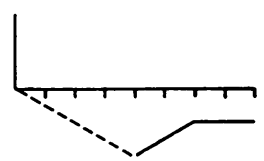

4

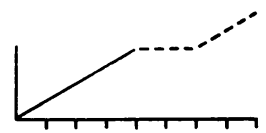

5

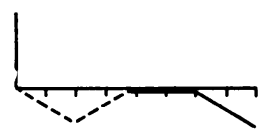

6
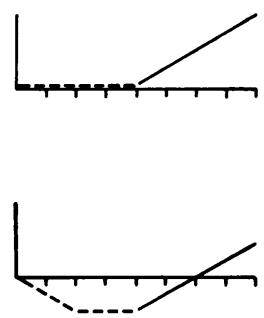

8

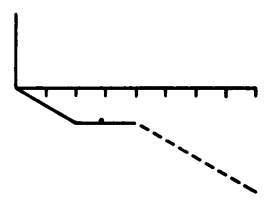

9

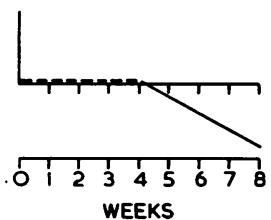

Fig. 2.-Effects in eighteen patients.
REST PAIN
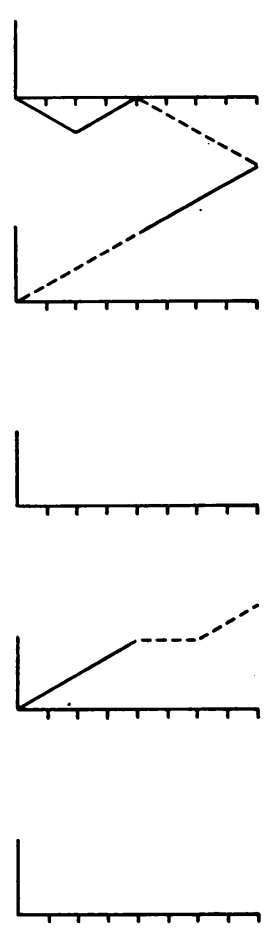

14

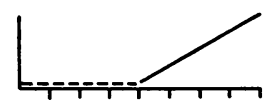

15
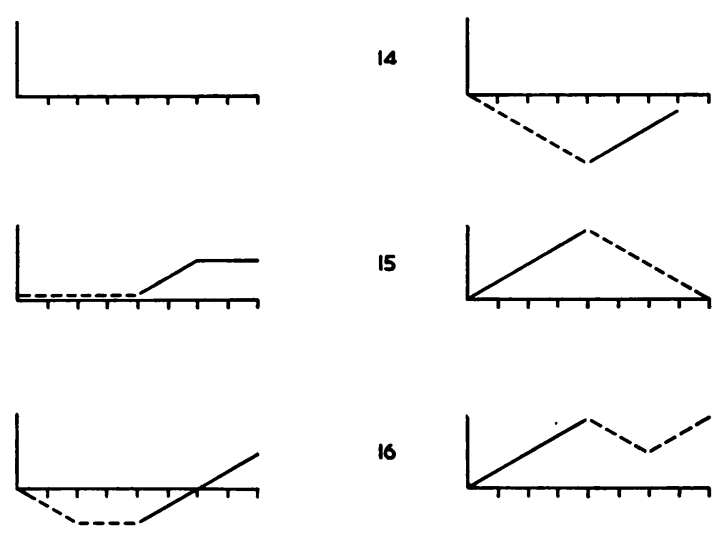

16
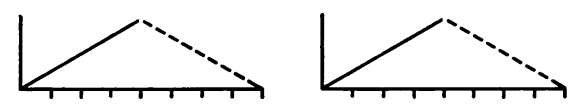

17
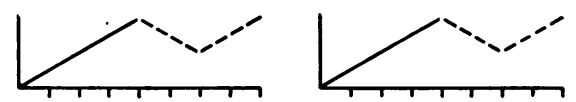

18
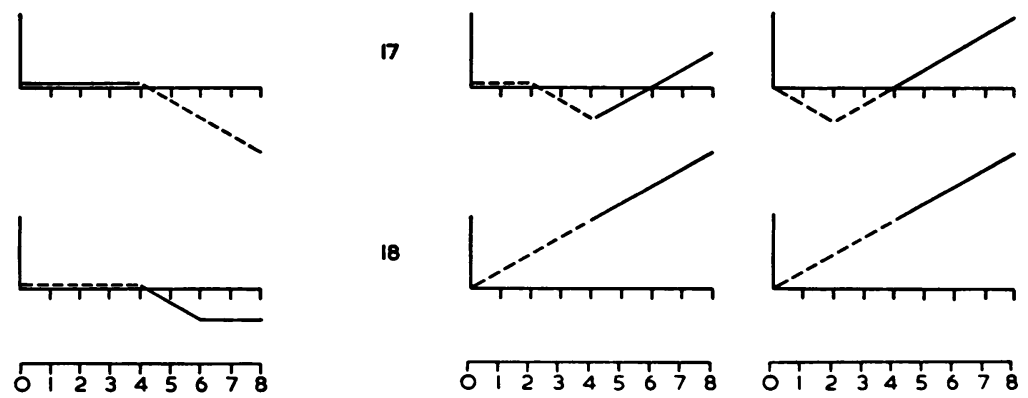
WEEKS
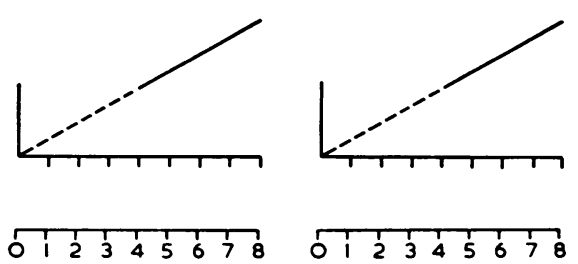

WEEKS

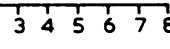

WEEKS

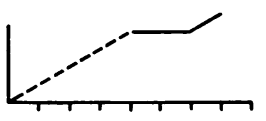

The curve rises, stays level, or falls according to whether the patient's symptoms are better, the same or worse at the end of a fortnight's treatment. 
For the relief of effort pain, fourteen of the eighteen patients preferred indomethacin to placebo, three preferred the placebo, and one rated them equally. For the relief of rest pain twelve of the eighteen patients preferred indomethacin to the placebo, two preferred the placebo, and two rated them equally. Two patients had not complained of rest pain at the start of the trial.

\section{Ranges of Hip Movement}

Three measurements were taken at each assessment:

(1) Intermalleolar distance (defined as distance in inches between both internal malleoli on combined maximum abduction of the hips);

(2) Total range of rotation of the hip joint (as reflected by the rotation of a line drawn on the sole of the foot measured on a protractor of 9 in. radius);

(3) Flexion of the hip joint as estimated by eye.

Taking the mean of the two measurements obtained during each type of medication, the intermalleolar distance improved 1 inch or more, with an average increase of $3 \frac{1}{2}$ in. in thirteen patients on indomethacin compared with the weeks on placebo. In one patient the measurements were greater during the weeks on placebo therapy, and in four patients there was less than one inch difference between the mean measurements for the two treatments (Fig. 5). No significant difference corresponding to the two treatments was noted in the degrees of rotation and

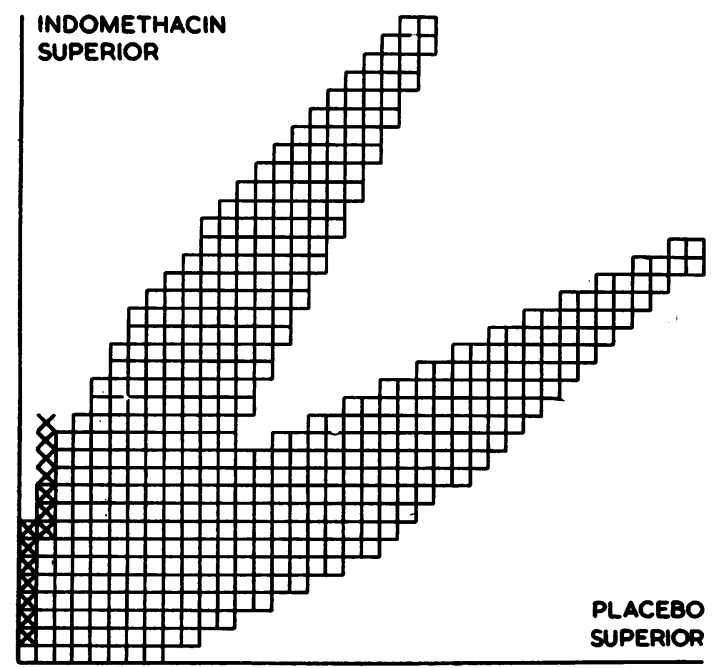

Fig. 5.-Net Preference for the whole 8-week period of the trial assessed by range of hip movements (intermalleolar distance). flexion of the hip joint, but the reproducibility of these two measurements was not high. The improvement in the range of combined abduction of the hips was equally distributed between those patients who were first treated with indomethacin and those who were first treated with placebo. The average intermalleolar distance at the start of the trial was not significantly different from the average at the end of the trial and improvement due to learning therefore plays no part in the improvement of intermalleolar distance associated with indomethacin administration.

\section{Adverse Effects of Indomethacin Administration}

The new formulation and the lower dosage used in this trial have not given rise to any serious adverse effects such as those described recently by Lövgren and Allander (1964) and by ourselves (Wanka and others, 1964) when using the compressed tablet formulation of indomethacin in rheumatoid arthritis. Patient fourteen, who was withdrawn from the trial after 3 weeks of indomethacin therapy (dosage then $150 \mathrm{mg}$./day) because of giddiness and indigestion, was retreated on Week 9, after the conclusion of the double-blind trial, with $50 \mathrm{mg}$. indomethacin daily with clinical benefit for 4 weeks with no ill-effects. The frequency of adverse effects in the eighteen patients is given in Table II. Adverse effects were not specifically asked for by name (to avoid suggestion) but each patient was asked the question "Have the tablets upset you in any way?" at each assessment. Again we noted the sometimes graphic description of adverse effects from placebo therapy. Thus Patient 14 started her treatment with three capsules daily on Day 0. Until Day 3 she noted no adverse effects, on Day 4 she had a severe frontal headache and felt she was going to faint, on Day 5 she had to go to bed and was crying all day and said

TABLE II

ADVERSE EFFECTS ENCOUNTERED DURING INDOMETHACIN AND PLACEBO ADMINISTRATION

\begin{tabular}{|c|c|c|c|c|c|}
\hline \multirow{2}{*}{\multicolumn{4}{|c|}{ Side-Effects }} & \multicolumn{2}{|c|}{ Patient-Weeks of Treatment } \\
\hline & & & & \multirow{2}{*}{$\begin{array}{c}\begin{array}{c}\text { Indomethacin } \\
\text { (Total 71) }\end{array} \\
5 \\
3 \\
2 \\
1 \\
2 \\
0 \\
1 \\
1 \\
1 \\
0\end{array}$} & \multirow{2}{*}{$\begin{array}{c}\begin{array}{c}\text { Placebo } \\
\text { (Total 72) }\end{array} \\
1 \\
1 \\
1 \\
2 \\
0 \\
2 \\
0 \\
0 \\
0 \\
1\end{array}$} \\
\hline $\begin{array}{l}\text { Epigastric Di } \\
\text { Giddiness . } \\
\text { Headache . . } \\
\text { Sleepiness .. } \\
\text { Diarrhoea .. } \\
\text { Depression } \\
\text { Palpitations } \\
\text { Air Hunger } \\
\text { Skin Rash . . } \\
\text { Dry Mouth }\end{array}$ & $\begin{array}{l}\text { nfort } \\
\ldots \\
\ldots \\
\ldots \\
\ldots \\
\ldots \\
\ldots \\
\ldots\end{array}$ & $\begin{array}{l}\cdots \\
\cdots \\
\cdots \\
\cdots \\
\cdots \\
\cdots \\
\cdots\end{array}$ & $\begin{array}{l}\cdots \\
\cdots \\
\cdots \\
\cdots \\
\cdots \\
\cdots \\
\cdots\end{array}$ & & \\
\hline \multicolumn{3}{|c|}{ Patient-Weeks of Treatment } & $\ldots$ & 16 & 8 \\
\hline
\end{tabular}


that she "simply couldn't stop crying" and "tears were simply streaming down", and on Day 6 she felt better. She attributed these troubles to the capsules she had been given, but when the sealed code for treatment sequence was examined at the end of the trial, it was found that during that period she had been taking placebo tablets.

\section{Laboratory Findings}

Special attention was paid to the indices of renal function since Norcross (1963) and other workers have reported evidence of progressive deterioration of renal function during long-continued indomethacin, a decrease in the renal clearance of creatinine, and a deterioration of function shown by the radioactive hippuran nephrogram. Of the eighteen patients who completed the trial, eight had a blood urea concentration greater than $45 \mathrm{mg}$. per $100 \mathrm{ml}$. at Day 0, i.e. before the administration of indomethacin, and in one patient the blood urea concentration at Week 0 was $70 \mathrm{mg}$. per $100 \mathrm{ml}$. At Day 57, after the trial, six patients still had a blood urea concentration greater than $45 \mathrm{mg}$. per $100 \mathrm{ml}$., in two patients the level had fallen to below that figure, and in two further patients whose blood urea concentration was initially a little below $45 \mathrm{mg}$. per $100 \mathrm{ml}$. the level had risen to slightly above that figure. The patient whose blood urea concentration was $70 \mathrm{mg}$. per 100 $\mathrm{ml}$. at Week 0 , had a blood urea of $68 \mathrm{mg}$. per 100 $\mathrm{ml}$. at Week 8. Thus we have found no tendency for the blood urea level to rise during this short-term trial and the variations seen were of a minor nature only, and no constant pattern emerged.

Similar remarks apply to the serum uric acid level. Early morning specimens of urine were examined at each assessment and in seven patients a trace of protein was detectable by the sulphosalicylic acid method at Week 0 of the trial. There was no tendency for this to increase during the trial or for other patients to develop proteinuria.

Fortnightly estimations of the haemoglobin, white blood cell count, and blood sedimentation rate also showed no tendency to change throughout the trial. Serum glutamic pyruvic transaminase and alkaline phosphatase levels as well as serum protein floculation tests which were done at Weeks 0,4 , and 8 of the trial also showed no abnormalities. Only in one patient was the serum bilirubin above normal limits on one occasion, and this patient also had a then untreated pernicious anaemia.

\section{Discussion}

Previous publications have stressed the high incidence of toxic effects of both a minor and a major nature during indomethacin administration (Hart and Boardman, 1963; Wanka and others, 1964; Percy, Stephenson, and Thompson, 1964) and have suggested that, although an effective drug, the frequency of toxic effects would limit its use to patients under close supervision and might in practice confine it to those in whom other methods of treatment had failed. These reports on the clinical effects of this drug were based on the use of the now obsolete compressed tablet formulation, and on higher total daily doses, usually between 200 and $300 \mathrm{mg}$. per day of treatment. In this trial smaller doses and a new formulation of indomethacin were employed and the total daily dosage of 75 to 150 mg. has proved to be sufficient to ease the patients' arthritic symptoms. The incidence of toxic and adverse effects has been reduced. Apart from these lower dosages we believe there is some virtue in employing an increasing dosage schedule, as we have already reported in a previous publication on indomethacin using the compressed tablet formulation. The relative merits of starting with full dosage of $150 \mathrm{mg}$. daily or starting with $75 \mathrm{mg}$. daily and increasing to $150 \mathrm{mg}$. daily cannot be assessed with a trial of this design. We have used a gradually increasing dosage scheme, similar to that adopted in this trial, with success in a number of other patients with rheumatoid arthritis and painful osteoarthritis of other joints, without the development of serious toxic effects during the initiation of treatment or its subsequent long-term maintenance.

In osteo-arthritis of the hip, as in other chronic joint diseases, the conclusions which can be drawn from a short-term trial such as this, extending only over a month of effective therapy, must necessarily be limited. The natural history of the disease and the anatomical changes which accompany degenerative joint disease of the hip are unlikely to be affected by any form of pain-relieving tablet. Nevertheless, for patients such as these who had refused, or were unsuitable for, more radical treatment, indomethacin should find a place as a useful palliative for pain and disability.

\section{Summary}

A double-blind crossover trial of 4 weeks with indomethacin in a dosage of 75-150 mg. per day, against a placebo, showed a significant preference for indomethacin both subjectively as regards effort and rest pain and objectively as regards the range of abduction of the hips. The new formulation and a lower dosage of this drug contributed to the reduced incidence of adverse and toxic effects.

We are indebted to Dr. G. Batten and Dr. H. C. H. Bull, who performed the barium meal examinations; to 
Dr. M. Rinsler for the biochemical estimation; to Dr. $O$. Savage for permission to include one of his patients in this trial; and to Dr. R. Hodgkinson of Merck Sharp and Dohme Ltd., Research Division, for the supply of indomethacin and placebo tablets and arrangements for the randomization of the initial treatment.

\section{REFERENCES}

Bross, I. (1952). Biometrics, 8, 188.

Council for International Organizations of Medical Sciences (UNESCO and WHO) (1963). "The Epidemiology of Chronic Rheumatism," Vol. II: "Atlas of Standard Radiographs of Arthritis". Blackwell Scientific Publications, Oxford.

Hart, F. Dudley, and Boardman, P. L. (1963). Brit. med.J., $2,965$.

Lövgren, O., and Allander, E. (1964). I Ibid., 1, 118.

Norcross, B. M. (1963). Arthr. and Rheum., 6, 290.

Percy, J. S., Stephenson, P., and Thompson, M. (1964). Ann. rheum. Dis., 23, 226.

Wanka, J., Jones, L. I., Wood, P. H. N., and Dixon, A. St.J. (1964). Ibid., 23, 218.
Traitement de la coxalgie par l'Indométhacine

Essai clinique contrôlé

RÉSUMÉ

Un essai de l'Indométhacine, comparée à une substance inerte pendant 4 semaines par la méthode de doubleblind crossover, aux doses de 75 à $150 \mathrm{mg}$. par jour, révéla une préférence significative pour l'Indométhacine, tant subjective à l'égard de la douleur au repos et à l'effort qu'objective à l'égard de l'étendue de l'abduction de la hanche. La nouvelle présentation et des doses plus basses de ce médicament ont contribué à la fréquence diminuée des effets toxiques et secondaires.

\section{Tratamiento de la osteoartritis de la cadera con Indometacina. Ensayo clinico controlado Sumario}

Un ensayo de la Indometacina, comparada a una substancia inerte durante 4 semanas por el método de double-blind crossover, en dosis diarias de 75 a $150 \mathrm{mg}$., evidenció una preferencia significativa para la Indometacina, tanto subjetiva respecto al dolor durante el descanso y el esfuerzo, como objetiva respecto a la magnitud de la abducción de la cadera. La neuva presentación y las dosis más bajas de este producto contribuyeron a la disminución de la frecuencia de los efectos tóxicos y secundarios. 